\title{
HUBUNGAN PENGETAHUAN IBU, ASUPAN PROTEIN DAN ASUPAN ZINK DENGAN STUNTING (PENDEK) PADA BATITA USIA 12 - 36 BULAN
}

\author{
Wike Juliyanti, Meriwati, Tetes Wahyu \\ Politeknik Kesehatan Kementerian Kesehatan Bengkulu, Jurusan Gizi, \\ Jalan Indragiri Nomor 03 Padang Harapan Kota Bengkulu \\ Wike_juliyanti@yahoo.com
}

\begin{abstract}
Stunting (short) is a chronic malnutrition can affect growth of infants and children due to inadequate food intake. The purpose of this study determine the relationship of mother's knowledge, the intake of protein and zinc with stunting (short) in toddlers aged 12-36 months. This study used a cross sectional design. The population is all children under the age of 12-36 months, the sample in this study amounted to 64 people the techniques used are systematic random sampling. Analysis of the data using chi square and logistic regresion test. The results showed that the mother's knowledge there is almost half of the respondents who are less knowledgeable about stunting, protein intake in children aged 12-36 months are almost half less, zinc intake in children aged 12-36 months are almost all respondents less, nutritional status of children 12-36 months of age are most of the stunting, there was no correlation between maternal knowledge and zinc intake with stunting in children aged 12-36 months, and there was association protein intake with stunting in children aged 12-36 months.
\end{abstract}

Keywords : mother's level of knowledge, protein intake, intake of zinc, stunting and children $12-36$ months

\begin{abstract}
Abstrak : Stunting (pendek) merupakan kekurangan gizi kronis yang menyebabkan terganggunya pertumbuhan bayi dan anak-anak karena kurang memadainya asupan makanan. Tujuan penelitian ini mengetahui hubungan pengetahuan ibu, asupan protein dan zink dengan stunting (pendek) pada batita usia 12-36 bulan. Penelitian ini menggunakan desain cross sectional. Populasi adalah seluruh anak batita usia 12-36 bulan, sampel dalam penelitian ini berjumlah 64 orang teknik yang digunakan adalah sistematik random sampling. Analisis data dengan menggunakan analisis chi square dan regresi logistik. Hasil penelitian menunjukkan bahwa pengetahuan ibu terdapat hampir sebagian responden yang berpengetahuan yang kurang tentang stunting, asupan protein pada batita usia 12-36 bulan terdapat hampir sebagian yang kurang, asupan zink pada batita usia 12-36 bulan terdapat hampir seluruh responden kurang, status gizi batita usia 12-36 bulan terdapat sebagian besar yang stunting, tidak ada hubungan tingkat pengetahuan ibu dan asupan zink dengan stunting pada batita usia 12-36 bulan, serta ada hubungan asupan protein dengan stunting pada batita usia 12-36 bulan.
\end{abstract}

Kata Kunci : pengetahuan ibu, asupan protein, asupan zink, stunting dan batita

Masa batita merupakan masa keemasan (golden age) yang akan mempengaruhi dan menentukan masa depan seseorang. Pada masa ini, status gizi perlu diperhatikan untuk mencegah terjadinya masalah gizi ganda yaitu gizi lebih dan gizi kurang. Kekurangan zat gizi pada masa batita dapat menyebabkan rendahnya pertumbuhan tinggi badan sehingga anak menjadi lebih pendek dari anak dengan status gizi normal (Nasution, 2013).
Stunting (pendek) di Indobesia merupakan masalah yang kerap kali diabaikan karena dianggap tidak akan mempengaruhi masa depan anak. Sebagian besar masyarakat tidak mempermasalahkan lambatnya pertumbuhan tinggi badan anak saat batita. Selagi anak masih sehat dan lincah, stunting (pendek) bukanlah masalah yang perlu diatasi (Nasution, 2013). 
Pengetahuan merupakan salah satu yang mempengaruhi status gizi (Supariasa, 2002). Menurut Notoatmodjo (2002), pengetahuan adalah hasil tahu dan ini terjadi setelah orang melakukan penginderaan terhadap suatu ob-jek tertentu. Dengan pengetahuan ibu baik maka ibu dalam merencanakan menu makanan yang sehat dan bergizi bagi dirinya dan keluarganya dalam upaya memenuhi zat gizi yang diperlukan pun baik (Merryana, 2012).

Terganggunya pertumbuhan bayi dan anak-anak karena kurang memadainya asupan makanan dan terjadinya penyakit infeksi berulang, yang mengakibatkan berkurangnya nafsu makan dan meningkatkan kebutuhan metabolic (Caufield et al, 2006).

Makanan yang baik adalah semua makanan segar yang memenuhi kebutuhan gizi tubuh kita, yaitu yang mengandung unsurunsur hidrat arang, protein, lemak, vitamin, mineral (seperti zink), air, dan zat-zat penting lainnya seperti serat, enzim dan antioksidan

Zink merupakan zat gizi yang esensial dan telah mendapat perhatian yang cukup besar akhir-akhir ini. Kehadiran zinc dalam tubuh akan sangat mempengaruhi fungsi kekebalan tubuh, sehingga berperan penting dalam pencegahan infeksi oleh berbagai jenis bakteri pathogen, dan apabila kekurangan asupan zink dampaknya adalah terhambatnya pertumbuhan (Almatsier, 2005).

Berdasarkan penelitian yang sudah ada, kekurangan zink pada saat anak-anak dapat menyebabkan stunting (pendek) (pendek) dan terlambatnya kematangan fungsi seksual. Akibat lain dari kekurangan zinc adalah meningkatkan resiko diare dan infeksi saluran nafas (Almatsier, 2005).

Berdasarkan hasil Riset Kesehatan Dasar (Riskesdas) 2010, untuk skala nasional, prevalensi anak batita stunting (pendek) sebesar $35,6 \%$ atau turun 1,2 \% disbandingkan tahun 2007 (36,8\%), dan angka tertinggi kejadian stunting (pendek) yakni pada usia 12-23 bulan dengan presentase sebesar $18,5 \%$ dengan kategori pendek, dan 23,0\% dengan kategori sangat pendek.

Berdasarkan penelitian Ramli et al (2009) yang dilakukan di Provinsi Maluku,
Indonesia, prevalensi stunting (pendek) anak usia 12 hingga 36 bulan adalah 38,4 \% sedangkan anak usia 0-11 bulan prevalensi Stunting (pendek) adalah $29 \%$. Martorell, Khan dan Schroeder mengatakan bahwa gangguan pertumbuhan linier atau Stunting (pendek) terjadi terutama dalam 1 sampai 3 tahun pertama kehidupan dan merupakan cerminan dari efek intraksi antara kurangnya asupan, lingkungan serta infeksi (Ramli, 2009).

Kejadian Stunting (pendek) sering dijumpai pada anak usia 12-36 bulan dengan prevalensi sebesar 38,3-41,5\%. Sedangkan prevalensi batita Stunting (pendek) di wilayah kerja Puskesmas Kayu Kunyit Kecamatan Manna Kabupaten Bengkulu Selatan pada tahun 2011 yaitu $20 \%$ dari 160 batita yang diukur dan merupakan Puskesmas ke dua tertinggi angka kejadian Stunting (pendek) bila dibandingkan dengan Puskes-mas lain seperti Puskesmas Kota Manna yang hanya 6,9 \% dan Puskesmas Pasar Mannna 15,6 \% (Dinkes Bengkulu Selatan, 2011).

Berdasarkan survey awal di Puskesmas Kayu Kunyit dari jumlah batita umur $12-36$ bulan sebanyak 332 orang dan yang mengalami Stunting (pendek) atau PB ku-rang menurut umur sebanyak 127 batita atau sekitar 38,2 \% (Puskesmas Kayu Kunyit, 2012)

Berdasarkan survey awal penelitian pada 6 orang batita Stunting (pendek) (pendek), bahwa pengetahuan ibu kurang sebanyak 4 orang dan baik sebanyak 2 orang, asupan protein yang kurang sebanyak 2 orang yaitu $<77 \%$ dan baik 4 orang yaitu $\geq 77 \%$. Pada asupan zink yang kurang sebanyak 2 orang yaitu $<77 \%$ dan baik 4 orang yaitu $\geq 77 \%$.

\section{BAHAN DAN CARA KERJA}

Penelitian ini merupakan penelitian survey analitik dengan pendekatan cross sectionnal. Populasi dalam penelitian ini adalah seluruh anak batita usia 12-36 bulan yang ada di wilayah kerja Puskesmas Kayu Kunyit Kecamatan Manna Kabupaten Bengkulu Selatan tahun 2013 yang berjumlah 359 batita, sedangkan sampel berjumlah 64 orang yang diambil secara sistematik random 
sampling. Data dianalisis secara univariat, bivariat dan multivariat.

\section{HASIL}

Tabel 1. Distribusi Frekuensi Stunting, Pengetahuan Ibu, Asupan Protein dan Asupan Zink

\begin{tabular}{lcc}
\hline \multicolumn{1}{c}{ Variabel } & F & \% \\
\hline Status Gizi & & \\
Baik & 27 & 42,2 \\
Kurang & 37 & 57,8 \\
Pengetahun Ibu & & \\
Baik & 36 & 56,2 \\
Kurang & 28 & 43,8 \\
Asupan Protein & & \\
Baik & 34 & 53,1 \\
Kurang & 30 & 46,9 \\
Asupan Zink & & \\
Baik & 10 & 15,6 \\
Kurang & 54 & 84,4 \\
\hline
\end{tabular}

Tabel 1 menunjukkan sebagian besar $(57,8 \%)$ batita mengalami stunting (pendek), hampir sebagian $(43,8 \%)$ pengetahuan ibu tentang stunting kurang, hamper sebagian $(46,9 \%)$ asupan protein kurang, hamper seluruh $(84,4 \%)$ asupan zink kurang.

\section{Analisis Bivariat}

Analisis ini dilakukan untuk mengetahui hubungan variabel bebas dengan variabel terikat dengan uji statistic chi-square.

Table 2 Hasil Analisis Hubungan Pengetahuan Ibu, Asupan Protein dan Asupan Zink

\begin{tabular}{|c|c|c|c|c|c|}
\hline \multirow{3}{*}{ Variabel } & \multicolumn{4}{|c|}{ Status Gizi } & \multirow{3}{*}{$p$} \\
\hline & \multicolumn{2}{|c|}{ Stunting } & \multicolumn{2}{|c|}{ Normal } & \\
\hline & $\mathbf{F}$ & $\%$ & $\mathbf{F}$ & $\%$ & \\
\hline \multicolumn{6}{|l|}{ Pengetahun Ibu } \\
\hline Kurang & 20 & 71,4 & 8 & 28,6 & \multirow{2}{*}{0,091} \\
\hline Baik & 17 & 47,2 & 19 & 52,8 & \\
\hline \multicolumn{6}{|l|}{ Asupan Protein } \\
\hline Kurang & 23 & 76,7 & 7 & 23,3 & \multirow{2}{*}{$0,009^{*}$} \\
\hline Baik & 14 & 41,7 & 20 & 58,8 & \\
\hline \multicolumn{6}{|l|}{ Asupan Zink } \\
\hline Kurang & 34 & 63 & 20 & 37 & \multirow{2}{*}{0,112} \\
\hline Baik & 3 & 30 & 7 & 70 & \\
\hline
\end{tabular}

$* \mathrm{p}<0,01$ sangat bermakna

Berdasarkan tabel 2 diketahui bahwa ibu yang pengetahuannya kurang dan memiliki batita stunting (pendek) adalah sebesar $71,4 \%$, sementara ibu yang pengetahuannya baik dan memiliki batita normal adalah sebesar 52,8\% dan tidak ada hubungan yang bermakna antara pengetahuan dengan stunting (pendek) batita usia 12-36 bulan dengan nilai $p$ value $0,091>0,05$, bahwa batita yang asupan proteinnya kurang dan memiliki batita stunting (pendek) adalah sebesar $76,7 \%$, sementara batita yang asupan proteinnya baik dan memiliki batita normal adalah sebesar 58,8\% dan ada hubungan yang bermakna antara asupan protein dengan stunting (pendek) batita usia 12-36 bulan dengan nilai $p$ value $0,009<0,05$, bahwa batita yang asupan zinknya kurang dan memiliki batita stunting (pendek) adalah sebesar $63 \%$, sementara batita yang asupan zinknya baik dan memiliki batita normal adalah sebesar $70 \%$ dan tidak ada hubungan yang bermakna antara asupan zink dengan stunting (pendek) batita usia 12-36 bulan dengan nilai $p$ value $0,112>0,05$.

\section{Analisis Multivariat}

Tabel 3. Hasil Uji Regresi Logistik Tingkat Pengetahuan Ibu, Asupan Protein dan Asupan Zink

\begin{tabular}{|c|c|c|c|c|}
\hline \multirow{2}{*}{$\begin{array}{c}\text { Variabel } \\
\text { Independen }\end{array}$} & \multicolumn{2}{|c|}{ Tahap 1} & \multicolumn{2}{|c|}{ Tahap 2} \\
\hline & p value & $\operatorname{Exp}(B)$ & p value & $\operatorname{Exp}(B)$ \\
\hline $\begin{array}{l}\text { Pengetahuan } \\
\text { Ibu }\end{array}$ & 0,063 & 3,178 & - & - \\
\hline Asupan Protein & $0,006^{*}$ & 7,642 & $0,003 *$ & 7,642 \\
\hline Asupan Zink & $0,030 *$ & 6,472 & $0,020 *$ & 6,472 \\
\hline
\end{tabular}

Ket : Pertimbangan untuk uji ini dilihat dari nilai $p$ value $\leq$ 0,05 , jika $p$ value > dari 0,05 maka variabel tersebut dikeluarkan dari uji selanjutnya

Berdasarkan tabel 4 dapat dijelaskan Analisis kedua variabel tanpa tingkat pengetahuan diperoleh kesimpulan bahwa asupan protein dan asupan zink memiliki $p$ value $<0,25$ yaitu asupan protein $(0,003)$ dan asupan zink $(0,020)$, sehingga semua variabel masuk ke analisis multivariat.

Hasil analisis multivariat menunjukkan bahwa setelah variabel tingkat pengetahuan dikeluarkan asupan protein memiliki nilai Exp (B) tertinggi yaitu 6,839, artinya asupan protein yang kurang berpeluang terjadi stunting (pendek) pada batitanya sebanyak 6,839 kali dibanding batita dengan asupan protein baik. 


\section{PEMBAHASAN}

\section{Hubungan Pengetahuan Ibu dengan Stunting pada Batita Usia 12-36 Bulan}

Hasil penelitian menunjukkan bahwa tidak terdapat hubungan yang bermakna antara pengetahuan ibu dengan batita stunting (pendek). Penelitian ini sejalan dengan penelitian Suhendri (2009) di Surabaya, yang mendapatkan hasil bahwa tidak ada hubungan pengetahuan ibu dengan status gizi batita dengan $p$ value 0,350 , dimana ibu yang pengetahuan yang tinggi dari 104 orang terdapat 46 orang yang memiliki status gizi yang baik pada batitanya. Defisit pangan disertai distribusi pangan antar anggota keluarga yang didasari pengetahuan atau perilaku gizi yang belum memadai berakibat meunculnya masalah kurang gizi (Adisasmito, 2007).

Pengetahuan gizi ibu merupakan salah satu faktor yang mempengaruhi konsumsi pangan dan status gizi. Pengetahuan yang kurang dan salah konsepsi tentang kebutuhan pangan dan nilai pengan merupakan masalah yang sudah umum. Masalah kurang gizi bisa disebabkan karena kurangnya pengetahuan tentang gizi atau kemampuan untuk menerapkan informasi tersebut dalam kehidupan sehari-hari (Supariasa, 2002).

Pengetahuan gizi dipengaruhi oleh beberapa faktor, di samping pendidikan yang pernah dijalani, faktor lingkungan sosial dan frekuensi kontak dengan media masa juga mempengaruhi pengetahuan gizi. Salah satu penyebab terjadinya gangguan gizi adalah kurangnya pengetahuan gizi atau kemampuan untuk menerapkan informasi tentang gizi dalam kehidupan sehari-hari.

Pengetahuan ibu tentang stunting diwilayah kerja Puskesmas Kayu Kunyit berdasarkan penelitian yang dilakukan tidak terdapat hubungan yang bermakna antara pengetahuan ibu tentang stunting (pendek) dengan kejadian stunting (pendek). Pengetahuan gizi ibu tentang stunting (pendek) tidak mempengaruhi status gizi batita. Seorang ibu di wilayah kerja Puskesmas Kayu Kunyit tersebut walaupun tidak mengerti tentang stunting (pendek) tetapi ibu mengerti tentang asupan makanan yang baik yang harus dikonsumsi batitanya. Pengetahuan ibu tentang stunting (pendek) tidak mempengaruhi status gizi batita secara langsung. Status gizi batita secara langsung dipengaruhi oleh asupan makan batita serta pengetahuan tentang gizi yang baik untuk batita tersebut.

\section{Hubungan Asupan Protein dengan Stunting pada Batita Usia 12-36 Bulan}

Hasil penelitian menunjukkan bahwa terdapat hubungan yang bermakna antara asupan protein dengan stunting (pendek). Penelitian ini sejalan dengan penelitian Wiyogowati (2012) di Bandung, yang mengatakan bahwa ada hubungan yang signifikan antara asupan protein pada batita usia 12-36 bulan dengan kejadian stunting (pendek).

Menurut Dewi, dkk (2013), protein merupakan sumber energi yang dibutuhkan tubuh untuh pertumbuhan dan perkembangan dan menghasilkan 4 kalori per gram sama dengan karbohdrat. Protein merupakan senyawa organik yang atom Carbon (C), hidrogen $(\mathrm{H})$, dan Oksigen $(\mathrm{O})$, serta Nitrogen $(\mathrm{N})$ dan disimpan dalam otot, tulang, darah, kulit, kartilago, dan limfe. Protein ini akan dipecah menjadi sumber energi apabila zat gizi karbohidrat dan lemak tidak mencukupi.

Protein sangat penting untuk perkembangan setiap sel dalam tubuh dan juga untuk menjaga kekebalan tubuh. Sebagai salah satu gizi yang sangat dibutuhkan oleh manusia, protein sangat penting di masa pertumbuhan. Konsumsi zat gizi yang kurang dalam waktu yang lama bisa menyebabkan Kurang Energi Protein (KEP) (Dewi, dkk, 2013).

Ukuran panjang badan yang rendah biasanya menunjukan keadaan gizi kurang akibat kekurangan zink dan protein. Panjang badan lahir faktor risiko stunting (pendek) karena apabila pertumbuhan yang lambat pada bayi yang dipengaruhi oleh retardasi linier yang terjadi sejak dalam kandungan, bayi tersebut memiliki ukuran panjang, berat dan lingkar kepala yang kurang dari ukuran normal sehingga bayi dapat mengalami gangguan pertumbuhan (Growth Faltering) sejak usia dini menunjukan resiko untuk 
mengalami stunting pada periode umur berikutnya (Whitney E, 2008).

Protein mempunyai fungsi penting dalam membangun dan memelihara sel jaringan tubuh. Fungsi utama protein adalah untuk pertumbuhan, bilamana tubuh kekurangan zat energi fungsi protein untuk menghasilkan energi atau untuk membentuk glukosa akan didahulukan. Bila glukosa atau asam lemak dalam tubuh terbatas, sel terpaksa menggunakan protein untuk membentuk glukosa dan energi. Glukosa dibutuhkan sebagai sumber energi sel-sel otak dan sistem saraf. Pemecahan protein tubuh guna memenuhi kebutuhan energi dan glukosa pada akhirnya akan menyebabkan melemahnya otot-otot (Almatsier, 2004).

Asupan protein batita di Wilayah Kerja Puskesmas Kayu Kunyit paling banyak mengkonsumsi bahan makanan sumber protein antara lain : telor, kacang-kacangan dan susu. Batita di Puskesmas Kayu Kunyit asupan makanan sumber protein masih ada yang kurang, hal ini bisa terjadi karena batita tersebut hanya mengkonsumsi satu jenis protein saja. Batita diwilayah kerja puskesmas tersebut sebagaian besar hanya mengkonsumsi makanan sumber hewani seperti hanya makan nasi dan telur tanpa ada tambahan makanan yang mengandung protein nabati dan zat gizi yang lainnya. Jadi untuk asupan proteinnya masih banyak yang kurang padahal asupan protein dapat mempengaruhi status gizi batita terutama untuk pertumbuhan tinggi badan batita.

\section{Hubungan Asupan Zink dengan Stunting pada Batita Usia 12-36 Bulan}

Hasil penelitian menunjukkan bahwa tidak terdapat hubungan yang bermakna antara asupan zink dengan stunting (pendek). Zink merupakan zat gizi yang esensial dan telah mendapat perhatian yang cukup besar akhir-akhir ini. Kehadiran zink dalam tubuh akan sangat mempengaruhi fungsi kekebalan tubuh, sehingga berperan penting dalam pencegahan infeksi oleh berbagai jenis bakteri patogen. Berdasarkan peneltian yang sudah ada, kekurangan zink pada saat anak-anak dapat menyebabkan stunting (pendek) dan terlambatnya kematangan fungsi seksual.
Akibat lain dari kekurangan zink adalah meningkatkan resiko diare dan infeksi saluran nafas (Supariasa, 2008).

Zink juga berinteraksi dengan hormonhormon penting yang terlibat dalam pertumbuhan tulang seperti samatomedin-c, osteocalcin, testosterone, hormone thyroid dan insulin. Kadar zink yang sangat tinggi ditulang dibanding dengan jaringan lain ini sangat penting dalam memperkuat maatriks tulang. Zink juga memperlancar efek vitamin D terhadap metabolisme tulang melalui stimulasi sintesis DNA di sel-sel tulang. Oleh karena itu , zink sangat erat kaitannya dengan metabolisme tulang, sehingga zink berperan secara positif pada pertumbuhan dan perkembangan dan sangat penting dalam tahap-tahap pertumbuhan dan perkembangan (Almatsier, 2009).

Penelitian ini sejalan dengan penelitian Anindita (2012), yang menyatakan bahwa tidak ada hubungan zink dengan stunting (pendek) pada batita, dimana nilai $\mathrm{p}$ value 0,032 . Kematian pada anak yang mendapat suplementasi zink juga lebih rendah. Prevalensi anak-anak yang memiliki berat badan menurut umur di atas persentil 80 juga secara signifikan lebih tinggi pada anak-anak yang mendapat suplementasi zink.

Arsenault (2008), menungkapkan hasil penelitian pada anak-anak di Peru membuktikan bahwa anak-anak yang menerima suplementasi zink memiliki berat tubuh lebih besar $0,41 \mathrm{~kg}$ dibandingkan dengan anak yang tidak mendapat zink dan terbukti bahwa defisiensi zink dapat menghambat pertumbuhan. Walaupun banyak penelitian yang mengungkapkan terdapat kaitan antara zink dengan pertumbuhan, namun hal yang berbeda ditunjukkan oleh hasil penelitian Walker (2007) yang menyatakan tidak ada pengaruh suplementasi tanpa zink terhadap pertumbuhan anak. Asupan zink kurang memiliki risiko menjadi stunting (pendek).

Penelitian di wilayah Puskesmas Kayu Kunyit ditemukan batita yang menjadi sampel rata-rata mengkonsumsi bayam, kangkung dan kacang-kacangan. Selain itu di wilayah kerja Puskesmas tersebut batita yang mengkonsumsi asupan makanan sumber 
zink seperti tiram, daging (terutama daging merah) dan produk susu masih kurang. Batita diwilayah tersebut sebagian besar kalau sudah makan nasi mereka sangat jarang diberi susu, padahal susu mengandung sumber zink yang cukup tinggi yang diperlukan untuk batita. Jadi untuk asupan zink batita di wilayah puskesmas tersebut hampir sebagian besar masih kurang.

\section{Faktor Dominan yang Berhubungan dengan Stunting}

Faktor dominan yang berhubungan dengan stunting (pendek) diperoleh berdasarkan analisis multivariat, dari ketiga variabel tersebut, dengan melihat nilai OR setiap variabel maka dapat disimpulkan bahwa variabel yang paling dominan berpengaruh dengan stunting (pendek) pada anak usia 1236 bulan adalah variabel asupan protein.

Hasil penelitian ini sejalan dengan penelitian yang dilakukan Wiyogowatii (2012) di Bandung, yang menyatakan bahwa asupan protein merupakan faktor yang dapat menyebabkan stunting (pendek). Menurut Dewi, dkk (2013), protein merupakan sumber energi yang dibutuhkan tubuh untuh pertumbuhan dan perkembangan dan menghasilkan 4 kalori per gram sama dengan karbohidrat. Protein merupakan senyawa organik yang atom Carbon $(\mathrm{C})$, hidrogen $(\mathrm{H})$, dan Oksigen $(\mathrm{O})$, serta Nitrogen $(\mathrm{N})$ dan disimpan dalam otot, tulang, darah, kulit, kartilago, dan limfe. Protein ini akan dipecah menjadi sumber energi apabila zat gizi karbohidrat dan lemak tidak mencukupi.

Protein merupakan zat gizi yang sangat penting karena yang paling erat hubungannya dengan pertumbuhan. Protein mengandung unsur $\mathrm{C}, \mathrm{H}, \mathrm{O}$ dan unsur khusus yang tidak terdapat pada karbohidrat maupun lemak yaitu nitrogen. Protein nabati dapat diperoleh dari tumbuh-tumbuhan, sedangkan protein hewani didapat dari hewan. Protein merupakan faktor utama dalam jaringan tubuh. Protein membangun, memelihara, dan memulihkan jaringan tubuh seperti otot, dan organ (Sharlin dan Edelstein, 2001).

Protein adalah bagian dari semua sel hidup dan merupakan bagian terbesar tubuh sesudah air. Seperlima bagian tubuh adalah protein, separonya ada didalam otot, seperlima didalam tulang dan tulang rawan, sepersepuluh di dalam kulit, dan selebihnya didalam jaringan lain dan cairan tubuh (Almatsier, 2009).

Saat anak tumbuh dan berkembang, protein adalah gizi yang sangat diperlukan untuk memberikan pertumbuhan yang optimal. Asupan protein harus terdiri sekitar $10 \%$ sampai $20 \%$ dari asupan energy harian. Rekomendasi ini untuk memastikan bahwa energi cukup disediakan untuk tubuh dari semua zat gizi sehingga protein hanya untuk pertumbuhan dan perkembangan jaringan tubuh (Sharlin dan Edelstein, 2001).

Protein selain untuk membangun struktur tubuh (pembentukan berbagai jaringan) juga akan disimpan untuk digunakan dalam keadaan darurat sehingga pertumbuhan atau kehidupan dapat terus terjamin dengan wajar. Kekurangan protein yang terus menerus akan menimbulkan gejala yaitu pertumbuhan kurang baik, daya tahan tubuh menurun, rentan terhadap penyakit, daya kreatifitas dan daya kerja merosot, mental lemah dan lain-lain (Sharlin dan Edelstein, 2001)

\section{KESIMPULAN}

Hampir sebagian ibu batita berpengetahuan kurang, hampir sebagian batita asupan protein kurang, hampir seluruh batita asupan zink kurang, sebagian besar batita mengalami stunting, tidak ada hubungan pengetahuan ibu dengan stunting, ada hubungan asupan protein dengan stunting, tidak ada hubungan asupan zink dengan stunting dan asupan protein paling dominan hubungannya dengan stunting.

Hasil penelitian ini diharapkan agar upaya penanggulangan pada batita stunting (pendek) dapat dilakukan lebih efektif oleh pihak Puskesmas khususnya Puskesmas Kayu Kunyit Kecamatan Manna Kabupaten Bengkulu Selatan dan perlu dilakukan kegiatan edukasi oleh pihak Puskesmas kepada ibu batita tentang pemberian makanan yang baik bagi anak sesuai dengan usia dan pertumbuhannya (pengetahuan gizi dan tumbuh kembang anak) agar dapat mening- 
katkan asupan gizi khususnya protein dan

\section{DAFTAR PUSTAKA}

Adisasmito. 2007. Sistem Kesehatan Ed.1. Jakarta: PT RajaGrafindo Persada.

Adriani, Meryyana. 2012. Pengantar Ilmu Gizi Masyarakat. Kencana Prenada Media Group: Jakarta.

Almatsier, Sunita, 2005. Prinsip Dasar Ilmu Gizi. Gramedia Pustaka Utama: Jakarta.

Caulfield LE. 2006. Stunting, wasting and micronutrient deficiency disorders. In:Jamison DT, Breman JG, Measham AR, Alleyne G, Cleason M, Evans DB, et al, editors. Disease control priorities in developing countries. 2nd ed. New York: The World Bank and Oxford University Press.

Dewi, Pujiastuti \& Fajar. 2013. Ilmu Gizi untuk Praktisi Kesehatan. Graha Ilmu:Yogyakarta.

Dinkes Bengkulu Selatan. 2011. Penilaian Status Gizi.

Hennighem, H, B \& McGregor. 2009. Gizi Kesehatan Masyarakat, Gizi dan Perkembangan Anak. EGC.

Ramli, Agho, Inder, Bowe, Jacobs and Dibley. 2009. Prevalence and Risk Factors for Stunting and Severe Stunting Among Under-fives in North Maluku Province of Indonesia. Biomed Central (BMC) Pediatrics. zink.

Sharlin, J \& Edelstein, 2001. Essentials of life Cycle Nutrition. Jones and Bartlett Publisher, LLC

Sudiman H. 2008. Stunting atau Pendek: Awal Perubahan Patologis atau Adaptasi Karena Perubahan Sosial Ekonomi yang Berkepanjangan. Media Litbang Kesehatan.

Suhendri. 2009. Faktor-Faktor Yang Berhubungan Dengan Status Gizi Anak Dibawah Lima Tahun (Balita) Di Puskesmas Sepatan Kecamatan Sepatan Kabupaten Tangerang Tahun 2009. Skripsi http://repository.uinjkt.ac.id/dspace/bitstream/1 23456789/2396/1/UCU\%20SUHENDRIFKIK.pdf

Supariasa, 2002. Penilaian Status Gizi. ECG: Jakarta Waterlow, J C. 1992. Protein Energi Malnutrition. Edward Arnold, A Division of Hodder \& Stoughton, London

Whitney E, Rolfes SR. 2008. Understanding nutrition. 11 th ed. USA: Thomson wadsworth.

WHO (2006) child growth standards: Length/heightfor-age, weight-for-age, weight-for-length, weight-for-height and body mass index-forage: Methods and development 